УДК 147.122

DOI https://doi.org/10.32849/2663-5313/2020.7.03

\title{
Мирослава Гудима,
}

канд. юрид. наук, дочент,

докторант кафедри иивільного права

Навчально-наукового юридичного інституту

ДВНЗ «Прикарпатсъкий начіональний університет імені Василя Стефаника»

\section{ОБГРУНТУВАННЯ ПАРАДИГМИ ОБОРОТОЗДАТНОСТІ РЕЧОВИХ ПРАВ}

Вказана наукова публікачія присвячена дослідженню можливості визнання майнових прав об'єктом иивільних правовідносин та аналізу проблематики оборотоздатності речових прав. Загальновідомо, що проблема об'єктів права сама по собі є складною, а питання включення до іх переліку майнових прав - й поготів. Водночас проблематика оборотоздатності майнових прав повинна отримати достатню теоретичну розробку та обгрунтування, оскільки має вагоме значення для розуміння сутності проявів динаміки суб'єктивних цивільних прав, у тому числі в аспекті розробки концепту ïх переходу. У статті широко представлені наукові погляди на проблематику обротоздатності майнових прав, проведено їх критичний аналіз та висловлено власну позичію, спрямовану на доведення оборотоздатності майнових прав. Задля достатньої теоретичної виваженості правових можливостей визнання за суб'єктивними правами властивостей об'єкта иивільних правовідносин в роботі здійснено звернення до загальнотеоретичної правової категорії «об’єкт правовідносин» та виявлено ї̈ смислове навантаження, а також проведено розмежування категорій змісту та об'єкта правовідносин в контексті дослідження майнових прав. Задля уникнення змішування аспектів розуміння майнового права, яке може виконувати функиію об'єкта і водночас змісту правовідносин, та спростування аргументів противників визнання майнових прав обороздатними об'єктами, які базують на иьому свої доводи, обгрунтовано, що ніякого змішування функцій майнових прав насправді не відбувається, адже варто визначати їхе функціональне призначення в рамках різних правовідносин: $у$ відносинах належності певного блага відповідному суб'єкту - майнові права виступатимуть в правовій якості елемента змісту правовідносин, а іх об’єктом - конкретне благо, на яке спрямовуються відповідні дї, тоді як в інших правовідносинах динамічного характеру (договірних, спадкових тощо) майнові права иілком вписуються в рамки загальнотеоретичного розуміння категорії «об’єкт цивільних правовідносин». Далі в роботі зосереджена увага на проблематиці цивільного обороту конкретного виду майнових прав - речових прав - та шляхом аналізу законодавчих норм і практики їх реалізачії підтверджено здатність речових прав виступати об'єктом в системі об'єктів иивільних правовідносин та можливість здійснення їх цивільного обігу.

Ключові слова: цивільний оборот, суб'єктивні цивільні права, об'єкти цивільних прав (правовідносин), майнові права, речові права.

Постановка проблеми. У сучасному цивільному обороті циркулює широке коло благ, в яке, окрім традиційно сприйнятих цивілістичною доктриною речей, входять й інші блага, зокрема майнові права. Останні нині вільно обертаються й практично конкурують за поширеністю 3 іншими об’єктами цивільних правовідносин. Така динаміка розвитку цивільних правовідносин вказує на необхідність удосконалення цивільного законодавства та проведення глибоких наукових досліджень. I якщо на законодавчому рівні факт оборотоздатності майнових прав $\epsilon$ визнаним, то на доктринальному - вказану проблему вважати вирішеною досить передчасно. Водночас проблематика оборотоздатності майнових прав повинна отримати достатню теоретичну розробку та обгрунтування, оскільки має вагоме значення для розуміння сутності проявів динаміки суб'єктивних цивільних прав, у тому числі в аспекті розробки концепту їх переходу. Оборотоздатність безтілесних об'єктів не так часто постає предметом наукових досліджень, а незначні наукові доробки в цій царині характеризуються спірністю та неоднозначністю.

Аналіз останніх досліджень і публікацій. На певних аспектах проблематики оборотоздатності об'єктів цивільних прав була сфокусована наукова увага таких учених, як В. А. Бєлова, В. В. Валах, Ю. О. Гладьо, А. С. Джабаєвої, О. С. Іоффе, Р. А. Майданика, О. І. Міхно, С. О. Мічуріна, І. А. Полуяхтова, В. Я. Погребняка, Д. І. Погрібного, М. О. Рожкової, С. А. Сліпченко, І. В. Спа- 
сибо-Фатєєвої, Є. О. Суханова, Ю. Е. Туктарова, Р. О. Халфіної, С. О. Харитонова, Г. Г. Харченка, Л. А. Чеговадзе, Я. М. Шевченка, С. І. Шимон, Р. Б. Шишки, В. Л. Яроцького, О. С. Яворської та ін. Незважаючи на те, що наукові зусилля вказаних авторів спрямовуються на побудову раціональної теорії оборотоздатності об'єктів цивільних прав, тим не менше мусимо констатувати наявність пласту наразі не вирішених, часто дискусійних питань, пов'язаних із включенням до цивільного обороту майнових, у тому числі й речових, прав.

Постановка завдання. Мета даної публікації полягає у науковому обгрунтуванні оборотоздатності суб'єктивних цивільних прав як передумови їх динаміки в аспекті концепту переходу речових прав.

Виклад основного матеріалу дослідження. Питання, пов'язані з оборотоздатністю об'єктів цивільних, прав знайшли своє закріплення в ст. 178 Цивільного кодексу (далі - ЦК) України, згідно з якою об’єкти цивільних прав можуть вільно відчужуватися або переходити від однієї особи до іншої в порядку правонаступництва чи спадкування або іншим чином, якщо вони не вилучені 3 цивільного обороту, або не обмежені в обороті, або не є невід'ємними від фізичної чи юридичної особи. Стаття 177 ЦК України до об'єктів цивільних прав відносить: речі, у тому числі гроші та цінні папери, інше майно, майнові права, результати робіт, послуги, результати інтелектуальної, творчої діяльності, інформацію, а також інші матеріальні і нематеріальні блага. Констатуємо, що в рамках вітчизняного законодавчого цивільно-правового категоріального апарату майнові права належать до об'єктів цивільних прав.

Незважаючи на законодавче визнання майнових прав об'єктами цивільних правовідносин, у цивільно-правовій теорії питання про можливість включення таких прав до об'єктів донині оспорюється.

Історично ще за дореволюційних часів панівною була думка про те, що продавати чи будь-яким іншим чином передавати можна лише речі, та не права. Ї̈̈ прибічниками були, зокрема, В. І. Сінайський, Г. Ф. Шершеневич [1, с. 373; 2, с. 414]. Серед сучасних дослідників теж трапляються прихильники такої позиції. Так, російський правник В. А. Бєлов заперечує можливість визнання майнового права об'єктом цивільного правовідношення; стверджуючи, що такими є виключно речі; а всі майнові права (в тому числі речові та зобов'язальні) як складник цивільного правовідношення є об'єктами цивільного обороту [3, с. 76-77]. Не можемо погоди- тися з позицією цього дослідника, оскільки обгрунтовуємо штучність розрізнення правових категорій «об'єкт цивільного обороту» та «об’єкт цивільних правовідносин», вважаючи, що цивільний оборот за своєю правовою природою і є правовідносинами. Крім того, надалі В. А. Бєлов не послідовний у дотриманні поглядів щодо розмежування вищевказаних понять, адже науковець визначає, що «оборот об'єктів цивільних правовідносин (цивільний оборот) - це сукупність випадків зміни носіїв суб'єктивних цивільних прав». Об'єктом цивільного правовідношення визнається «будь-яка субстанція, яка має відповідне юридичне значення і не співпадає з його суб'єктами, змістом, а також не входить до кола підстав його динаміки». У таке визначення, за словами самого автора, вписується традиційне розуміння об'єкта, яке закріплене в цивільному законодавстві, 3 пануванням речової концепції [3, с. 63]. Але ж із цього випливає висновок, що цивільний оборот як оборот об'єктів цивільних правовідносин $€$ оборотом речей, грошей, цінних паперів, іншого майна, майнових прав. Тож пропоноване відмежування цивільного обороту з його об'єктами від цивільного правовідношення 3 його власними об'єктами втрачає сенс.

Чимало дослідників, висловлюючи позицію щодо неможливості віднесення майнових прав до об'єктів правовідносин, звертаються до загальнотеоретичних правових категорій i стверджують, що традиційно права належать до змісту правовідносин, а тому неможливо одночасно відносити їх до числа об'єктів цивільних прав. Ми ж поділяємо протилежний підхід і вважаємо, що теоретичним грунтом для виявлення правових можливостей визнання за суб'єктивними правами властивостей об'єкта цивільних правовідносин є виявлення смислового значення загальнотеоретичної правової категорії «об'єкт правовідносин».

Існують певні субстанції (блага), властивості яких зумовлюють і впливають на змістову характеристику правовідносин, і саме проблема пошуку останніх виявляє сутність визначення категорії «об'єкт правовідносин». Термін «об’єкт правовідносин», таким чином, був сконструйований в чисто прагматичних цілях. Отже, традиційно під об’єктом правовідносин розуміється те, з приводу чого виникають й існують правовідносини, - це матеріальні і нематеріальні блага, властивості яких визначають можливу і належну поведінку суб’єктів правовідносин, до яких належать і суб'єктивні цивільні права.

Вищевказане розуміння «об'єкта прав (правовідносин)» та традиційне тлумачення змісту правовідносин наштовхують на висновок, що майнове право має подвійний сенс, 
а тому може розглядатися, з одного боку, як суб'єктивне право в якості складової частини змісту правовідносини, а з іншого - як об'єкт цивільних (правовідносин). У зв'язку з цим виникають запитання: як не допустити змішування цих аспектів розуміння майнового права і чи можливе одночасне виконання вказаною категорією функцій і об'єкта, і змісту правовідносин? В аспекті останнього цілком поділяємо позицію Ю. С. Поварова, що, коли йдетсья про майнові права як об'єкти, «ніякого змішання об'єкта правовідносини з правами і обов'язками, які утворюють зміст правовідносини, не відбувається, оскільки об'єктом правовідносин виступають права, що виникли в рамках інших правовідносин» [4, с. 39, 40]. У багатьох випадках, стверджує C. I. Шимон, доводи проти можливості майнових прав виступати об'єктами цивільного обороту є вразливими через те, що грунтуються на розгляді майнових прав як об'єктів в межах їхніх «власних» правовідносин, насправді ж у «своєму власному» правовідношенні суб'єктивне право виступає елементом його змісту, а об'єктом може стати виключно в «іншому» правовідношенні [5, с. 127].

Повністю підтримуючи позиції вчених і надалі їх розвиваючи, відзначимо, що визнання цивільного обороту системним явищем, що складається 3 «динамічних» (переважно зобов'язальних) правовідносин та відносин «статичного характеру» (речових правовідносин), дає нам можливість дійти висновку, що в останніх (відносинах належності певного блага відповідному суб'єкту) майнові права (скажімо, речові права) виступатимуть у правовій якості елемента змісту правовідносин, а їх об'єктом буде конкретне благо, на яке спрямовуються відповідні дії, тоді як у «динамічних» правовідносинах, які опосередковують перехід благ від суб'єкта до суб'єкта, майнові права цілком вписуються в рамки загальнотеоретичного розуміння категорії «об'єкта цивільних правовідносин».

В. А. Бєлов відзначив, що зміст правовідношення (до якого входить суб'єктивне цивільне право) не може водночас бути об'єктом хоч би й іншого правовідношення; інакше довелося б визнати за правовідношенням значення юридичного факту [6, с. 17]. Нам видається, що вказана автором аргументація не достатня для заперечення можливості існування двох правовідносин 3 різними місцем майнових прав у їхній структурі. Перші правовідносини (відносини щодо належності благ певним суб'єктам) не ведуть до виникнення других (відносин щодо переходу прав на ці об'єкти), а тільки $€$ необхідною передумовою для такого, а тому вважатись юридичним фактом не можуть.
Інша когорта дослідників теж висловлюють думки щодо неможливості віднесення майнових прав до об'єктів правовідносин, однак вже 3 інших підстав. Так відзначається, що право - це ідеальний феномен, який не може передаватися саме в силу своєї ідеальності. Термін «передача» властивий речам, предметам матеріального світу, право ж моментально виникає і припиняється. Оскільки право - явище ідеального характеру, то і немає ніяких часових проміжків між його припиненням та виникненням [7, с. 61 , 62]. Насправді ж, сфері ідеального взагалі не властиві часово-просторові категорії, а конструкція переходу прав як засіб юридичної техніки має спеціальну мету - відобразити те, що у певний момент відбулася зміна суб'єкта правовідносин.

У свою чергу А. С. Джабаєва для обгрунтування такої ж позиції апелює до неможливості існування безсуб'єктних прав, тому зауважує, що будь-яке право завжди належить конкретному суб'єкту - кредитору або уповноваженій особі. Для функціонування в якості об'єктів обороту майнові права повинні відокремитися від їх носія [8, с. 45]. Як контраргумент такій позиції застосуємо тезу В. Касапа, згідно 3 якою «приналежність прав» не повинна розглядатися в аналогічному сенсі 3 «приналежністю речей». Це не певна цінність, яку можна пов'язати з особою суб'єкта, швидше, має місце їх зв’язок з певними ситуаціями, які охоплені об'єктивним правопорядком. Суб'єктивне право, так само як і юридичний обов'язок, не може бути «моїм» або «чужим». Воно не належить, а лише діє у зв'язку з тим, що особа «потрапляє» в цивільно-правову ситуацію в правовому статусі суб'єкта. Особа в період існування цивільних правовідносин перебуває в особливому правовому стані їх суб'єкта - уповноваженої або зобов'язаної [9, с. 127]. Реалії сьогодення свідчать, що суб'єктивне право поступово перестає ототожнюватися зі своїм носієм. Воно може набувати властивостей якогось зовнішнього щодо уповноваженої особи блага, стає самостійною майновою цінністю, з приводу якої між учасниками цивільного обороту виникають різні правовідносини. Справедливо відзначає Ю. Є. Туктаров: «Право як об'єкт обороту мислиться як дещо зовнішне по відношенню до його володільця, об'єктом його належності чи розпорядження» $[10$, с. 129$]$.

Визнання суб'єктивних прав об'єктами цивільних прав і правовідносин стало можливим завдяки розвитку цивільного обороту і появі нових потреб ділової практики. На думку М. А. Москалець, деякі суб'єктивні 
права в цивільному обороті отримують властивості самостійних майнових благ. До таких дослідниця відносить, зокрема права вимоги за зобов'язаннями, виключні права, бездокументарні цінні папери, які, на її думку, є не чим іншим, як відносними суб'єктивними правами. Щодо таких прав, вважає М. А. Москалець, можливе розпорядження [11, с. 134-141]. О. I. Міхно, виокремлюючи ознаки майнових прав, звертає увагу на відсутність нерозривного зв'язку iз суб'єктами цивільних правовідносин, що й надає, на думку автора, можливості їх переходу на правових підставах від одного суб'єкта до іншого [12, с. 46].

В юридичній науці виділяють такі ознаки майнового права як об'єкта цивільних прав: 1) виступає засобом реалізації майнового інтересу; 2) відчужуване, тобто тісно не пов'язане з особою його носія; 3) володіє економічною цінністю, яка визначається за допомогою грошової оцінки самого права; 4) не властиве суб'єкту спочатку в силу самого факту його існування $[13$, с. 46]. Тобто для кваліфікації суб’єктивного цивільного права майновим та здатним виконувати функції оборотоздатного об'єкта необхідною $€$ наявність майнової цінності (здатності до грошової оцінки) та можливості передання.

У літературі висловлюється думка, що право може виступати виключно об'єктом зобов'язальних правовідносин, тобто право в динаміці, отже, об’єктом є лише право вимоги. У статиці ж право $є$ складником змісту правовідношення [14, с. 72]. Проте зобов'язальний характер правовідносин, об'єктом яких виступають права, ще не є свідченням того, що переходу підлягають тільки права вимоги, адже різновидом майнових прав $\epsilon$ також речові права, які на підставі правочинів чи інших юридичних фактів у відповідних зобов'язальних правовідносинах можуть переходити від одних суб'єктів до інших. Отже, речові права можуть бути складниками структури не лише речових, а й зобов'язальних правовідносин, однак як їх різні структурні елементи. Влучно пише C. I. Шимон, що з того факту, що майнове право є об'єктом зобов'язальних правовідносин, не випливає висновок, що таким майновим правом може бути виключно зобов'язальне право [5, с. 127]. Як зазначають прибічники позиції включення речових прав в об'єкти цивільних прав, «немає ніяких відмінностей в суб'єктивному цивільному праві незалежно від того, яке воно - речове або зобов'язальне» [15, с. 18]. Вважаємо раціональною позицію К. І. Скловського, що цивільний оборот є оборотом речових і зобов'язальних прав [7, с. 60].
Виходячи із законодавчого визначення майна, майнові права - це суб'єктивні права учасників правовідносин на окрему річ, сукупність речей, а також майнові права та обов'язки, відтак це права, пов'язані з володінням, користуванням і розпорядженням майном, а також з матеріальними вимогами, що виникають із приводу розподілу й обміну майна. Тобто, окрім речових прав, до складу майнових прав слід відносити права вимоги. Обгрунтованою видається позиція, згідно 3 якою поняття «майнові права» $є$ ширшим за обсягом за поняття «речові права». Підтримуємо наукові позиції щодо співвідношення майнових прав і права власності як загального і його частини відповідно [16, с. 5]; про те, що майнові права повною мірою охоплюють систему речових та зобов'язальних прав [17, с. $233 ; 18$, с. 396-401]. Формулювання такого висновку дає можливість речові права, як складник майнових прав, у зв'язку із законодавчим визнанням останніх об'єктом цивільних прав відносити до об'єктів цивільних прав.

Ще одне підтвердження можливості речових прав бути об'єктом правовідносин віднаходимо шляхом аналізу законодавчих норм та практики їх реалізації. Приміром, вітчизняне законодавство визнає за деякими речовими правами на чужі речі властивості об'єктів правовідносин (зокрема, здатність виступати об'єктом правочинів). Так, ч. 2 ст. 413 ЦК України закріпила, що за загальним правилом право користування земельною ділянкою, наданою для забудови (суперфіцій), може відчужуватися або передаватися землекористувачем у порядку спадкування, крім певних винятків, встановлених законодавством; така ж властивість визнана за правом користування чужою земельною ділянкою для сільськогосподарських потреб (ч. 2 ст. 407 ЦК України). На користь можливості речових прав бути об'єктами інших цивільних прав, на думку В. В. Валах, свідчать положення законодавства про заставу (іпотеку), а саме ст. 5 Закону України «Про іпотеку», яка передбачила, що предметом іпотеки може бути право оренди чи користування нерухомим майном, яке надає орендарю чи користувачу право будувати, володіти та відчужувати об'єкти нерухомого майна $[19$, с. $313 ; 13$, с. 48$]$.

\section{Висновки}

Резюмуємо, що суб'єктивне цивільне майнове право може розглядатися в двох іпостасях: як елемент змісту правовідносини та в ролі самостійного об'єкта цивільних правовідносин. До того ж ніякого змішання об'єкта правовідносин з правами і обов'язками, які 
утворюють зміст правовідносин в контексті майнових цивільних прав, не відбувається, оскільки визначення ролі останніх у вказаних аспектах відбувається в рамках різних правовідносин. Природа майнового права зумовлює різну характеристику зв'язків суб'єкта з відповідниими майновими благами, що знаходить свій вияв у «статиці» та «динаміці» правовідносин: якщо зв'язок суб'єкта із реальним майновим благом є безпосереднім і саме шляхом впливу на нього відбувається задоволення інтересів уповноваженої особи, то йдеться про статичні відносини належності (речові правовідносини), якщо ж зв'язок суб'єкта 3 річчю і правом на неї набуває властивостей якогось зовнішнього щодо уповноваженої особи блага, стає самостійною майновою цінністю, то відносини, які виникають із приводу таких благ і опосередковують їх рух від одних суб'єктів до інших, характеризуються як «динамічні». Отож, майнове цивільне право, з одного боку, може бути змістом абсолютних (речових) правовідносин, зокрема відносин власності, де на рівні догми об'єктом цього різновиду цивільних правовідносин визнаються речі, а з іншого - об'єктом інших (скажімо, зобов'язальних, спадкових) правовідносин, які забезпечують динаміку цивільних правовідносин.

Можна сміливо стверджувати, що натепер у цивілістиці майнові права - це самостійні блага, окремий оборотоздатний об'єкт цивільних правовідносин. Однак не слід ототожнювати майнові права як об'єкти цивільних прав з правами вимоги, адже останні є лише різновидом майнових прав, не вичерпуючи їх. Законодавчі норми та практика їх реалізації, а також доктринальні положення цивілістики свідчать, що речові права можуть виступати об'єктом правовідносин «динамічного характеру» (зобов'язальних, спадкових тощо), які опосередковують їх перехід від одного суб'єкта до іншого і виступають складником системи правовідносин цивільного обороту, тобто виступають оборотоздатним об'єктом.

\section{Список використаних джерел:}

1. Синайский В. И. Русское гражданское право. Москва : Статут, 2002. 638 с.

2. Шершеневич Г. Ф. Курс гражданского права. Тула : Автограф, 2001. 720 c.

3. Белов В. А. Объект субъективного гражданского права, объект гражданского правоотношения и объект гражданского оборота: содержание и соотношение понятий. Объекты гражданского оборота : сб. ст. Москва : Статут, 2007. С. 6-77.

4. Поваров Ю. С. Предприятие как объект гражданских прав. Самара: Самарский университет, 2002. $176 \mathrm{c}$.
5. Шимон С. I. Теоретичні передумови виокремлення майнових прав як об'єктів цивільних правовідносин. Наукові записки Інституту законодавства Верховної Ради Украйни. 2012. № 5. C. $125-128$.

6. Белов В. А. Сингулярное правопреемство в обязательстве. Опыт исторического исследования, теоретической и догматической конструкции и обобщения российской судебной практики. Москва : ЮрИнфоР, 2000. 288 с.

7. Скловский К. Механизм перехода права и последствия цессии. Хозяйство и право. 2002. № 2. С. $60-67$.

8. Джабаева А. С. Имущественное право как обьект гражданского оборота. Сибирский юридический вестник. 2003. № 3. С. 44-49.

9. Касап В. Проблеми співвідношення правонаступництва та заміни осіб у зобов'язанні як цивільно-правових категорій. Visegrad journal on human rights. Part 2. 2016. № 1. С. 125-130.

10. Туктаров Ю. Е. Имущественные права как объекты гражданско-правового оборота Актуальные проблемы гражданского права. Вып. 6. Москва: Норма, 2003. С. 101-136.

11. Москалець М. А. Субьективние права и обьекти права собственности. Вестник Пермского университета. 2010. Випуск 2 (8). С. 134-141.

12. Міхно О. І. До питання про визначення майнових прав як об'єктів цивільних правовідносин. Бізнес-адміністрування в умовах турбулентної економіки : матеріали міжнар. наук.практ. Інтернетконференції. Харків. нац. ун-т міськ. госп-ва ім. О. М. Бекетова. Харків: ХНУМГ ім. О. М. Бекетова. 2015. С. 44-47.

13. Валах В. В. Теоретико-правовое обоснование существования конструкции «право на право» в украинском и российском гражданском праве. Вісник Одеського наиіонального університету. Серія «Правознавство». 2011. Т. 16. Вип. 15. С. 41-54.

14. Лысенко А. Н. Имущество в гражданском праве России. Москва: Деловой двор, 2010. 200 с.

15. Чеговадзе Л. А. Структура и состояние гражданского правоотношения. Москва: Статут, $2004.542 \mathrm{c}$.

16. Чорна Ж. Л. Цивільно-правовий захист майнових прав та інтересів малолітніх і неповнолітніх осіб : автореф. дис. ... канд. юр. наук: 12.00.03. Львів, 2005. 17 с.

17. Шимон С. I. Поняття майнових прав в контексті конвенції про захист прав людини й основоположних свобод. Університетські наукові записки: часопис Івано-Франківського ун-ту права ім. Д. Галищького. Вип. З. Івано-Франківськ, 2011. С. $227-235$.

18. Другова В. Г. Деякі проблемні питання правової природи іпотеки. Держава і право : зб. наук. праць. Юридичні і політичні науки. Вип. 41. 2008. C. 396-401.

19. Про іпотеку : Закон України від 05.06.2003 № 898-IV. Відомості Верховної Ради України. 2003. № 38. Ст. 313. URL: https:// zakon.rada.gov.ua/laws/show/898-15\#Text (дата звернення: 02.07.2020) 
Myroslava Hudyma. Substantiation of the paradigm of conveyance of real rights

This scientific article is devoted to the study of the possibility of recognizing property rights as an object of civil law and analysis of the transferability of property rights. It is well known that the problem of objects of law is complex in itself, and the question of including property rights in their list is even more complicated. At the same time, the issue of transferability of property rights must receive sufficient theoretical development and justification, as it is crucial to understand the essence of the dynamics of subjective civil rights, including development of the concept of their transfer. The article widely presents scientific views on the issue of transferability of property rights, critically analyzes them and expresses its own position aimed at proving the transferability of property rights. The researcher refers to the general theoretical legal category «object of legal relations» and reveals its semantic loading, as well as makes a distinction of categories of the content and object of legal relations in the context of the study of property rights for sufficient theoretical balance of legal possibilities of recognition of subjective rights of properties being an object of civil legal relations. In order to avoid confusing aspects of understanding «property law», which can serve as an object and at the same time the content of legal relations and refuting the arguments of opponents of recognizing property rights as transferability objects, which base their arguments on it, it is justified that no mixing of property rights functions occurs, because it is necessary to determine their functional purpose in different legal relationships: in the relationship of belonging a particular good to the subject - property rights will act as a legal element of the content of legal relations, and their object - a specific good to which appropriate action is directed, at the same time in other legal relations of a dynamic nature (contractual, hereditary, etc.) property rights fully fit into the framework of the general theoretical understanding of the category «object of civil relations». Further, the paper focuses on the issue of civil circulation of a particular type of property rights - property rights and confirms the ability of property rights to act as an object in the system of objects of civil law and the possibility of their civil circulation by analyzing legislation and practice of its implementation.

Key words: civil turnover, subjective civil rights, objects of civil rights (legal relations), property rights, property rights, real rights. 